\title{
CAN GOVERNMENT FUNDING REVIVE ZOMBIE ENTERPRISES? EVIDENCE FROM LISTED CHINESE MANUFACTURING ENTERPRISES
}

\author{
Yudi YANG, Yong QI ${ }^{*}$, Shuo YANG \\ School of Business Administration, Northeastern University, 110169 Shenyang, China
}

Received 17 August 2020; accepted 21 June 2021

\begin{abstract}
This study tests how different types of government funding affect the recovery of zombie enterprises in the manufacturing sector of China. The results show that funding for production and innovation can revive zombie enterprises in expanding industries, while funding for interest cannot. Furthermore, funding for production and innovation can share costs, increase investment in selling or innovation, and promote the scaling down of businesses through external governance effects, helping zombie enterprises to recover. Finally, none of the funding types can revive zombie enterprises in contracting industries; these can recover only through access to larger overseas markets.
\end{abstract}

Keywords: government funding, zombie enterprises, recovery mechanism, industry life cycle, Chinese economy, transformation and upgrading.

JEL Classification: L53, L6, O23.

\section{Introduction}

China's 2019 gross domestic product growth rate was 6.1\%, the lowest since 1990; this indicates that China is attempting to shift from a rapid growth mode to one of high-quality development. The government has undertaken interventions and supply-side structural reforms aimed at achieving high-quality development. Zombie enterprises are companies with poor earnings that survive only through creditor or government protection (Kane, 1987). They consume social resources, seriously harm the operations of normal enterprises, and hinder supply-side structural reforms in China. Therefore, solving the problem of zombie enterprises is crucial for ensuring China's economic stability. Financial assistance, the main instrument of government economic intervention, plays an important role in optimizing the allocation of social resources. However, the prevalent outlook maintains that government funding that does not match practical corporate needs can turn normal enterprises into

\footnotetext{
*Corresponding author. E-mail: yqi@mail.neu.edu.cn
} 
zombie enterprises (Song et al., 2019). Conversely, government funding can play a positive role in addressing market failures, signaling, and external governance; therefore, it can also help zombie enterprises to recover, an issue neglected by existing studies. The present study therefore explores whether government funding can revive zombie enterprises; it also investigates the impact of different funding types and industry life cycle stages to provide a scientific basis for improving policies, to thereby revive zombie enterprises. This approach could enable a significant step forward in China's economic reform.

Previous studies on zombie enterprises have focused on Japanese enterprises in the 1990s. These studies demonstrated how zombie enterprises harmed the macro and micro economy using various identification methods (Ahearne \& Shinada, 2005; Caballero et al., 2008; Peek, 2008). The distribution and causes of China's zombie enterprises and their impact on normal enterprises have been studied since 2016 (Nie et al., 2016; Shen, 2016; Tan et al., 2016; Huang \& Chen, 2017; Jiang \& Lu, 2017; Wang \& Liu, 2018). Fang and Sun (2019), Jiang and Wang (2018), and Jiang et al. (2018) have discussed ways for zombie enterprises to recover.

Japanese zombie enterprises are strongly affected by banks. Chinese zombie enterprises, however, are more affected by the government, as they receive financial support from both the government and state-owned banks (Zhou et al., 2018). Therefore, investigating how government funding impacts zombie enterprises in China is important. Previous studies have found that government funding may have helped create Chinese zombie enterprises (Luan et al., 2018; Niu \& Gao, 2018; Dai et al., 2019; Chang et al., 2020); however, Huang and Guo (2019) suggested that raising funding levels could help transform and upgrade state-owned zombie enterprises. This shows that the effect of government funding on zombie enterprises in China has been explored, but the results are inconsistent. This study, therefore, examines this issue from a novel perspective.

First, most studies regarded government funding as a contributing factor for zombie enterprises and investigated its static effect using empirical strategies. They ignored the potentially positive effect of appropriate funding strategies on zombie-enterprise recovery. Therefore, the dynamic recovery mechanisms triggered by government funding remain underexplored; these mechanisms constitute the primary problem considered in this study. Second, existing studies have investigated the government funding's impact on zombie enterprises; however, they have not considered differences among government funding types. Two exceptions, Luan et al. (2018) and Song et al. (2019), discussed the impact of funding for research and development $(\mathrm{R} \& \mathrm{D})$ and financing. Therefore, this study considers the differences in government funding types when investigating the impact of government funding on zombie-enterprise recovery. Third, existing literature also focused on government intervention and internal corporate governance; few studies have examined government funding along with the industrial demand environment. Whether or not the industry life cycle (the expansion and contraction of industrial demand) affects the results of government funding is a topic that deserves closer attention. In addition, the paths of recovery for zombie enterprises may differ, depending upon the different stages of the industry life cycle. For this reason, it is also important to research the impact of periodic expansion and contraction on industrial demand. 
By the above approaches, this study can help to supplement the existing literature and identify funding strategies that could potentially revive zombie enterprises to provide a theoretical basis for government development of industrial policies.

For the rest of this study, Section 1 briefly reviews the relevant research progress and proposes the hypotheses. The dataset and methodology are introduced in Section 2. Section 3 presents the empirical analysis. Section 4 further discusses the results. Finally, some conclusions and limitations are presented.

\section{Literature and hypotheses}

\subsection{Literature review}

This study reviews several aspects of the relevant literature, including the definition, identification, influence, causes, and recovery of zombie enterprises.

Zombie enterprises are defined as enterprises that are bailed out by creditors or banks. Gao and $\mathrm{Li}$ (2018) defined Chinese zombie enterprises as firms that have lost viability in the market and survive only on external assistance, such as government subsidies and bank loans. Even though these enterprises lose money over a long period and waste social resources, the dual protection from the government and banks prevents them from closing down.

The first identification criterion for zombie enterprises, the CHK method, was proposed by Caballero et al. (2008). This method determines whether an enterprise has obtained a loan subsidy (i.e., whether it is a zombie enterprise) by calculating the difference between the actual bank interest paid by the enterprise and the minimum interest required. Fukuda and Nakamura (2011) modified the CHK method by adding three standards (the FN-CHK method) to avoid confusing profitable enterprises receiving preferential bank credit with zombie enterprises. Zhang et al. (2016) included net profit after deducting government subsidies to the FN-CHK criterion, making it more representative of China's reality.

Using these identification criteria, studies have discussed how zombie enterprises negatively impact investment activities, information-disclosure quality, and productivity among normal enterprises (Lin, 2011; Kwon et al., 2015; Imai, 2016). Shen and Chen (2017) argued that Chinese zombie enterprises create overcapacity by crowding out normal enterprises. Tan et al. (2017), Li et al. (2018), and Wang et al. (2018) respectively examined how Chinese zombie enterprises harm normal enterprises by crowding out investment, distorting taxes, and hindering innovation.

From a new structural economics perspective, Shen (2016) found that the comparative advantages of factor endowment and technology can explain the emergence of zombie enterprises. Jiang and Wang (2018) argued that the causes of zombie enterprise creation involve capital and labor. Most studies have regarded government funding as an important factor in Chinese zombie enterprise creation (Liu et al., 2019; Dai et al., 2019; Zhang et al., 2020b). These studies provide evidence that can help to prevent the formation of zombie enterprises.

To eradicate existing zombie enterprises, some studies focused on factors that can revive them, including reducing employment, selling fixed assets, and purchasing collateral (Nakamura \& Fukuda, 2013; Jaskowski, 2015). Studies from China have also suggested that 
outward foreign direct investment, cutting bad assets, raising wages, and mixed-ownership reform can revive China’s zombie enterprises (Jiang \& Wang, 2018; Jiang et al., 2018; Zhu et al., 2018).

Importantly, when it comes to the relationship between government funding and zombie enterprises, existing studies commonly argue that government funding prevents inefficient enterprises from exiting the market by hampering market clearing, thus promoting the formation of zombie enterprises (Rao \& Wan, 2018). However, for existing zombie enterprises, few studies have considered the likely positive impact of government funding on their recovery. Using data from Shanghai's small and medium-sized enterprises, Luan et al. (2018) indicated that R\&D funding would worsen zombie enterprises. Liu et al. (2019) argued that government funding can reduce the capacity utilization rate of zombie enterprises.

Several tools have been shown to revive zombie enterprises. Fang and Sun (2019) found that reducing management costs may restore the viability of zombie enterprises. This can encourage spending for selling and innovation, which are conducive to market development and product upgrading. Moreover, increasing R\&D investment and total factor productivity can also foster economic transformation and upgrading (Xu et al., 2020) and have been proven to revive zombie enterprises (Jiang et al., 2018). Additionally, enterprise-strategy theory indicates that enterprises can use a contraction strategy to reverse unfavorable situations during crises; these include business decline, losses, and numerous non-performing assets. By contracting their business, enterprises can clarify their main goals, reconfigure internal resources, and improve utilization efficiency, thereby restoring core competitiveness (Markides, 1995). Zombie enterprises are closely linked to blind expansion and overcapacity in China; thus, scaling down could help them to recover. Overall, government funding's positive impacts on zombies' cost reduction, innovation, and scaling down could help them recover. These studies provide a basis for exploring how government funding impacts zombie-enterprise recovery.

The literature has made important contributions and provided a basis for exploring how government funding impacts the recovery of zombie enterprises; however, a deeper exploration of the relationships between the funding types, the industry life cycle, and recovery mechanisms of zombie enterprises is required. Therefore, this study tests the impacts of various funding types on the recovery of zombie enterprises across two market demand circumstances and discusses potential recovery paths.

\subsection{Theoretical hypotheses}

\subsubsection{Government funding and recovery of zombie enterprises}

Government-funding theory posits that different government funding types have different regulatory purposes and impacts on enterprises (Huergo \& Moreno, 2017). This motivates us to investigate how various funding types affect zombie enterprises' recovery. The literature suggests that funding for production, innovation, and interest are used most frequently by the government and are most closely related to zombie enterprises.

"Funding for production" means that the government provides subsidies to help enterprises expand production scale or absorb employment. The prevailing view is that zombie enterprise 
creation in China is closely related to the government's efforts to guarantee employment and maintain social stability by stimulating production (Rao \& Wan, 2018). However, corporatefinance theory holds that production funding can ease corporate financial constraints. Signal theory states that production funding can also send positive signals to the outside, directing injections of funds (Meuleman \& Maeseneire, 2012). Therefore, production funding could also help alleviate their financial difficulties, restoring their viability. Additionally, referring to external governance theory, correctly-allocated production funding could induce zombie enterprises to transform their production activities into fields with better market prospects (Peng et al., 2020). Overall, production funding can help zombie enterprises recover.

"Funding for innovation" means that the government provides enterprises with subsidies to encourage their innovation including knowledge development, technological upgrading, innovation application, and innovation cooperation. Zombie enterprise theory posits that a lack of product competitiveness due to a low innovation level can weaken corporate viability (Wang et al., 2018). Corporate innovation literature shows that innovation funding can compensate for the externality of innovation activities, helping enterprises improve their technical levels (Porter, 1990); this can help to revive them. The external governance effect of innovation funding is also significant, as the process and results of funded projects are always strictly supervised and reviewed by the government. This helps enterprises to identify the main direction of technological development and regulate the use of funds, which improves resource utilization efficiency. Therefore, innovation funding can help zombie enterprises to recover.

"Funding for interest" means that the government provides enterprises subsidies to pay the interest on loans for some purposes. Government intervention literature argues that the government tends to control state-owned banks for addressing corporate financing constraints by providing interest funding (Zhang et al., 2020a). However, zombie enterprise theory asserts that excessive corporate loans in the absence of good investment opportunities help create zombie enterprises (Song et al., 2019). Interest funding may allow zombies to pass on the risk of bankruptcy to governments and banks - at little cost - while maintaining zombie status. Projects that receive interest funding may be related to corporate production and innovation activities, but interest funding is not directly invested in corporate production and innovation. Although the government may attempt to guide zombie enterprises into transformation and upgrading by providing interest funding, the main project fund is provided by the bank and can be used freely by the enterprise. Considering the logic of information-asymmetry theory, the government, due to their limited supervision capacity, does not have full access to corporate information the application of loaned funds, weakening the regulatory effect of government funding. Conversely, zombie enterprises can reserve sufficient information in a favorable position; they do not have to invest all loans in transformation and upgrading activities with higher risks. Thus, they remain zombies. Based on the above, interest funding cannot promote transformation of zombie enterprises and revive them. The following hypotheses are proposed:

Hypothesis 1a: Funding for production and innovation have a positive effect on the revival of zombie enterprises;

Hypothesis 1b: Funding for interest has no significant effect on the revival of zombie enterprises. 


\subsubsection{Industry life cycle}

The periodic expansion and contraction of industrial demand often affect industrial-policy effectiveness (Maksimovic \& Phillips, 2008). Thus, whether the industry life cycle affects the effectiveness of government funding for zombie enterprises' recovery is worth examining. Based on the dynamic changes in industrial scale, the industry life cycle is classified into two separate stages: the demand-expansion stage and the demand-contraction stage. The former is when the scale of industrial demand has been growing at a high rate for a certain period, while the latter is when the growth rate of industrial demand is slowing down or even becomes negative.

Enterprises in industries at the demand-expansion stage of its life cycle (expanding industries) always have a strong motivation to increase production. They become zombie enterprises because their product or innovation ability cannot adapt to the market demand for high-quality products. Due to the strong market demand, zombie enterprises in expanding industries need only technology innovation and product quality improvements to regain their market share and recover. As stated in external-governance theory, production and innovation funding have strong planning and supervision effects, which can guide the transformation and upgrading of zombie enterprises and ease their financial constraints, helping them improve their operating efficiency and product competitiveness. Expanding market demand can also reduce the risks of transformation and upgrading, thus promoting zombie enterprises' recovery. In contrast, the insignificant impact of interest funding on recovery can be attributed to information asymmetry between enterprises and the government or to the weakening of governmental control and supervision. Expanded market demand cannot address this problem; thus, interest funding cannot revive zombie enterprises in expanding industries. Enterprises in industries at the demand-contraction stage of its life cycle (contracting industries) always face intense competition; thus, only enterprises that achieve major transformation and technological innovation can survive. Neither zombie enterprises themselves nor the government can afford the huge risks and costs of transformation and upgrading in the face of shrinking demand. Therefore, government funding only provides a recovery opportunity for zombie enterprises facing expanding demand. The following hypotheses are proposed:

Hypothesis 2a: Funding for production and innovation have a positive effect on the revival of zombie enterprises in industries at the demand-expansion stage of the industry life cycle;

Hypothesis 2b: Funding for interest has no significant effect on the revival of zombie enterprises in industries at the demand-expansion stage of the industry life cycle.

\section{Database and methodology}

\subsection{Sample and database}

From 2008 to the end of 2010, China launched a RMB 4,000 billion economic stimulus package to revive the economy. To avoid the interference of this policy, a set of sample covering 2012 to 2016 was selected. This study used the database of China Stock Market \& Accounting Research (CSMAR) built by Shenzhen GTA Education Tech Ltd., which includes the basic 
information and financial data of China's listed enterprises. This database has been widely used in previous empirical studies.

The CSMAR database is smaller than the Chinese industrial enterprises survey database, which has been used by previous studies; however, its data disclosure is more specific and standardized, providing detailed information including different funding types and debts. This study excluded enterprises that were listed and delisted between 2012 and 2016, as well as those marked as "special treatment", to avoid the interference of abnormal data, obtaining 5,020 observations during the five-year period for 1,004 manufacturing enterprises. Data on corporate revenues, assets, debt, and other information were collected from the CSMAR database. Information on government subsidy and R\&D investment was manually extracted from the annual reports of listed enterprises. The different databases were matched up using corporate names and stock codes.

\subsection{Identification of zombie enterprises}

This study identified zombie enterprises in China using the FN-CHK method, which has been widely used in mainstream studies. First, according to the $\mathrm{CHK}$ criterion proposed by Caballero et al. (2008), an enterprise has accepted subsidized credit if the minimum interest requirement is greater than the interest it has paid. Second, the method adopted by Fukuda and Nakamura (2011) modified the CHK method in terms of the profit and leverage ratio. Finally, the method of Zhang et al. (2016) corrected the bias caused by high government funding in the Chinese context by deducting government subsidies from corporate profits to identify zombie enterprises. The identification steps are as follows:

The minimum interest requirement to be paid $\left(R A_{i, t}\right)$ by enterprise $i$ in year $t$ is estimated by:

$$
R A_{i, t}=r s_{t-1} \times B S_{i, t-1}+\frac{1}{5} \sum_{j=1}^{5} r l_{t-j} \times B L_{i, t-1},
$$

where $B S_{i, t-1}$ and $B L_{i, t-1}$ are the short- and long-term liabilities of enterprise $i$ in year $t-1$, respectively. Further, $r s_{t-1}$ and $r l_{t-j}$ are the average short- and long-term prime rates in year $t$, respectively. The prime rate is 0.9 times the benchmark rate, according to the lower limit of the lending rate set by The People's Bank of China.

The estimated actual net interest payment of enterprise $i$ is:

$$
R M_{i, t}=R A_{i, t}-R B_{i, t}
$$

where $R B_{i, t}$ represents the interest income of enterprise $i$.

According to Fukuda and Nakamura's criterion, the information on corporate profits is employed to calculate zombie index $F N_{i, t}$ to avoid mistaking profitable enterprises receiving preferential bank credit for zombie enterprises:

$$
F N_{i, t}=\left(E B I T_{i, t}-R M_{i, t}\right) /\left(B S_{i, t-1}+B L_{i, t-1}\right),
$$

where $E B I T_{i, t}$ is the earnings before interest and tax of enterprise $i$ in year $t . B S_{i, t-1}+B L_{i, t-1}$ represents the sum of all bank loans of enterprise $i$ in year $t-1$. According to this traditional 
FN-CHK standard, enterprise $i$ can be considered a zombie enterprise when $F N_{i, t}<0$, the asset-liability ratio is greater than 0.5 , and the total liabilities in year $t$ are greater than those in year $t-1$.

Following Zhang et al. (2016), government subsidies are deducted from $E B I T_{i, t}$ to eliminate identification bias caused by government subsidies:

$$
F N_{i, t}^{a d}=\left(E B I T_{i, t}-S_{u b s i d y_{i, t}}-R M_{i, t}\right) /\left(B S_{i, t-1}+B L_{i, t-1}\right)
$$

According to the study's criteria, enterprise $i$ can also be considered a zombie enterprise when $F N_{i, t}^{a d}<0$, the asset-liability ratio is greater than 0.5 , and total liabilities in year $t$ are greater than those in year $t-1$. Using this method, 634 zombie enterprises are identified from 5,020 observations (a rate of 12.6\%). Using the method of Fang and Sun (2019), an enterprise is regarded as recovering in year $t$ if it is a zombie in year $t-1$ but is normal in years $t$ and $t+1$. In this sample, $5.6 \%$ of the zombie enterprises recovered.

\subsection{Empirical model}

\subsubsection{Benchmark model}

The following model was established to test the effect of government funding on the recovery of zombie enterprises:

$$
\begin{aligned}
& \text { Zom_out }_{i, t}=\beta_{0}+\beta_{1} \operatorname{Prodsu_{i,t-1}}+\beta_{2} \text { Innovsu }_{i, t-1}+\beta_{3} \text { Loansu }_{i, t-1}+ \\
& \beta_{4} \text { Control }_{i, t}+\beta_{r}+\beta_{t}+\beta_{s}+\varepsilon_{i, t}
\end{aligned}
$$

where Zom_out $t_{i, t}$ is a dummy variable. The value of Zom_out $t_{i, t}$ is 1 if zombie enterprise $i$ becomes normal in year $t$, and 0 otherwise.

The explanatory variable $P r o d s u_{i, t-1}$ reflects production funding received by enterprise $i$ in year $t-1$. This variable is measured by the ratio of production funding to revenue, where production funding is quantified as the gross subsidy amount of projects funded to expand production, reduce operating costs, and stimulate the development of industries or enterprises. Innovsu $u_{i, t-1}$ indicates innovation funding received by enterprise $i$. This variable is measured by the ratio of innovation funding to revenue, where innovation funding is quantified as the gross subsidy amount of projects funded for innovation, $R \& D$, patents, and technology upgrading. Loansu $u_{i, t-1}$ indicates interest funding received by enterprise $i$. This variable is measured by the ratio of interest funding to revenue, where interest funding is quantified as the gross subsidy amount of projects with discounted interest.

The theoretical analysis shows that the paths of influence for interest funding may differ between production and innovation funding, even though interest funding projects may be related to production and innovation activities. Projects receiving interest funding are always marked as "interest discount" on the government grants lists in annual corporate financial statements; this allows us to distinguish them from projects receiving production and innovation funding in terms of variable measurement and to empirically consider the differences in their impacts on zombie enterprises.

Control represents control variables such as asset-liability ratio (Leverage), assets (Size), listed years (Age), cash flow (CFO), ownership (SOE), and Tobin's Q value (Tobinq). $\beta_{s}$, $\beta_{t}$, 
and $\beta_{r}$ respectively indicate the fixed effects of sections, years, and regions, and $\varepsilon$ denotes a random error term. The calculation employed a logit model and clustering standard errors at the individual level. For non-intensity variables (Size, CFO, Age, Revenue, and Patent), their natural logarithms were considered to address dimensional differences and heteroscedasticity. A 99\% winsorization was employed to eliminate the influence of outliers. Table 1 shows the definitions of variables and data sources. Table 2 reports the descriptive statistics.

\subsubsection{Heckman model}

Exploring how government funding impacts zombie-enterprise recovery presents two potential endogeneity problems. The first is caused by reverse causality. An enterprise's zombie status could affect government funding behavior. This problem in the benchmark model has been solved by lagging the explanatory variables. The second problem involves sample selection bias, as unobservable factors concerned about government funding may impact the state of enterprises. The Heckman (1979) two-step method was used as a solution.

Table 1. Definitions of variables

\begin{tabular}{|c|c|c|}
\hline Variable & Definition & Source of data \\
\hline Zom_out & $\begin{array}{l}\text { Dummy, equals } 1 \text { if a zombie enterprise becomes a normal } \\
\text { enterprise in year } t \text { according to the standard of this study }\end{array}$ & $\begin{array}{l}\text { Authors' } \\
\text { calculation }\end{array}$ \\
\hline Prodsu & Ratio of production funding to revenue & Annual report \\
\hline Innovsu & Ratio of innovation funding to revenue & Annual report \\
\hline Loansu & Ratio of interest funding to revenue & Annual report \\
\hline Size & Amount of assets & CSMAR \\
\hline Leverage & Asset-liability ratio & CSMAR \\
\hline Age & Listed years & CSMAR \\
\hline $\mathrm{CFO}$ & Cash flow & CSMAR \\
\hline SOE & Dummy, equals 1 for state-owned enterprises & CSMAR \\
\hline Revenue & Operating revenue & CSMAR \\
\hline PRDI & Ratio of private R\&D investment to revenue & Annual report \\
\hline Patent & Number of corporate patent applications & $\dagger$ \\
\hline Tobinq & Value of Tobin's Q & CSMAR \\
\hline Zom_out2 & $\begin{array}{l}\text { Dummy, equals } 1 \text { if a zombie enterprise becomes a normal } \\
\text { enterprise in year } t \text { according to the traditional FN-CHK standard }\end{array}$ & $\begin{array}{l}\text { Authors' } \\
\text { calculation }\end{array}$ \\
\hline Zom_out3 & $\begin{array}{l}\text { Dummy, equals } 1 \text { if a zombie enterprise becomes a normal } \\
\text { enterprise in year } t \text { according to the standard of this study after } \\
\text { excluding samples that never become zombies }\end{array}$ & $\begin{array}{l}\text { Authors' } \\
\text { calculation }\end{array}$ \\
\hline Sale & Ratio of selling expenses to revenue & CSMAR \\
\hline Scale & Ratio of main business income to assets & CSMAR \\
\hline Export & Ratio of export amount to revenue & Annual report \\
\hline
\end{tabular}

Note: $\uparrow$ Website of China’s National Intellectual Property Administration (2009). 
Table 2. Descriptive statistics

\begin{tabular}{|l|c|c|c|c|c|}
\hline \multicolumn{1}{|c|}{ Variable } & Observation & Mean & Standard deviation & Min & Max \\
\hline Zom_out & 4,016 & 0.0555 & 0.2290 & 0 & 1 \\
\hline Prodsu & 5,020 & 0.0038 & 0.0073 & 0 & 0.0475 \\
\hline Innovsu & 5,020 & 0.0048 & 0.0082 & 0 & 0.0497 \\
\hline Loansu & 5,020 & 0.0002 & 0.0009 & 0 & 0.0060 \\
\hline Size & 5,020 & 8.0975 & 1.0667 & 6.1638 & 11.3781 \\
\hline Leverage & 5,020 & 0.3739 & 0.1894 & 0.0426 & 0.8193 \\
\hline Age & 5,020 & 2.0919 & 0.5998 & 0.6931 & 3.3322 \\
\hline CFO & 5,020 & 6.2912 & 0.0197 & 6.2083 & 6.3827 \\
\hline SOE & 5,020 & 0.2928 & 0.4551 & 0 & 1 \\
\hline Revenue & 5,020 & 7.4584 & 1.2789 & 4.9753 & 11.2024 \\
\hline PRDI & 5,020 & 0.0398 & 0.0309 & -0.0008 & 0.1906 \\
\hline Patent & 5,020 & 2.7175 & 1.4119 & 0 & 6.5191 \\
\hline Tobinq & 5,020 & 2.5586 & 1.9125 & 0.2591 & 10.2953 \\
\hline Zom_out2 & 4,016 & 0.0702 & 0.2555 & 0 & 1 \\
\hline Zom_out3 & 794 & 0.3552 & 0.4789 & 0 & 1 \\
\hline Sale & 5,020 & 0.0811 & 0.0850 & 0.0004 & 0.8008 \\
\hline Scale & 5,020 & 0.9182 & 0.0695 & 0.6350 & 1.2762 \\
\hline Export & 5,020 & 0.1733 & 0.2141 & 0 & 0.8784 \\
\hline
\end{tabular}

In this method, a probit model is used in the first stage to predict the probability of an enterprise receiving funding of various types. The equation is

$$
\begin{aligned}
& \text { Subd }_{i, t}=\beta_{0}+\beta_{1} \text { Revenue }_{i, t}+\beta_{2} \text { Patent }_{i, t}+\beta_{3} \text { PRDI }_{i, t}+\beta_{4} \text { Size }_{i, t}+ \\
& \beta_{5} \text { Leverage }_{i, t}+\beta_{6} \text { SOE }_{i, t}+\beta_{7} \text { Tobinq }_{i, t}+\beta_{s}+\beta_{r}+\varepsilon_{i, t},
\end{aligned}
$$

where $S u b d_{i, t}$ denotes the level of government funding, represented by three dummy variables

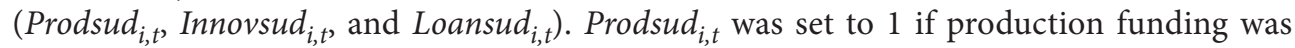
greater than the median value, and 0 otherwise. The dummy variable of innovation funding (Innovsud $_{i, t}$ ) had the same values. However, as less than $50 \%$ of the observations obtained interest funding, this study set Loansud ${ }_{i, t}$ to 1 if enterprise $i$ obtained interest funding, and 0 otherwise. The variables affecting the level of government funding include Revenue (operating revenue), $P R D I$ (private R\&D intensity), Patent (number of patent applications), Size, Leverage, SOE, Tobinq, $\beta_{s}$, and $\beta_{r}$. The inverse Mills ratio (Lambda) was obtained from Model 6 and was included as an independent variable in the second-stage estimation of Model 5 to help mitigate possible sample selection bias.

\subsubsection{Simultaneous equation model}

The above theoretical analysis posits that zombie enterprises can recover their viability by following different paths. First, reducing cost pressure can stimulate increased spending on 
advertising and marketing, which, in turn, can foster market development and help zombie enterprises to recover market share. Second, increased R\&D investment, which enhances production efficiency and product competitiveness, has been shown to revive zombie enterprises. Additionally, enterprise-strategy theory indicates that a contraction strategy can clarify corporate goals and optimize resource allocation, improving recovery probability. Therefore, a simultaneous equation model was used to investigate how government funding revives zombie enterprises through three channels: increasing spending on selling, increasing private $\mathrm{R} \& \mathrm{D}$ intensity, and scaling down business.

The first step of the simultaneous equation model assumed that the channels are impacted by funding variables and control variables. The next step assumed that the recovery of zombie enterprises is related to the channels, funding variables, and control variables. The simultaneous equation model was established:

$$
\left\{\begin{array}{l}
\text { Channel }_{i, t}=\gamma_{0}+\gamma_{1} \text { Sub }_{i, t}+\gamma_{2} \text { Control }_{i, t}+\gamma_{r}+\gamma_{t}+\gamma_{s}+\omega_{i, t} \\
\text { Zom_out }_{i, t}=\beta_{0}+\beta_{1} \text { Channel }_{i, t-1}+\beta_{2} \text { Sub }_{i, t-1}+\beta_{3} \text { Control }_{i, t}+\beta_{r}+\beta_{t}+\beta_{s}+\varepsilon_{i, t}
\end{array},\right.
$$

where Channel is represented by three variables, Sale, PRDI, and Scale. Sale denotes spending on selling, $P R D I$ denotes private R\&D intensity, and Scale denotes business scale. Control1 includes Size, Leverage, Age, CFO, Tobinq, SOE, and Export (export intensity). The settings for Control2 and fixed effects are the same as those in the benchmark model.

\section{Results and analysis}

\subsection{Government funding's impact on zombie enterprises}

Columns 1 to 4 of Table 3 show the results of the benchmark model. The coefficients of funding for production and innovation are significantly positive; however, the coefficient for interest is not significant, whether the three funding types enter the model separately or simultaneously. Greater production and innovation funding for zombie enterprises increases the probability of their recovery. The calculation of the marginal effect in Model (5) shows that the probability of recovery increases by $1.45 \%$ when production funding intensity increases by $1 \%$, whereas it increases by $1.21 \%$ when innovation funding intensity increases by $1 \%$. These results are consistent with the theoretical expectations and therefore, Hypotheses $1 \mathrm{a}$ and $1 \mathrm{~b}$ are verified positively.

The results of the Heckman model, used to address possible endogeneity (Columns 9 to 11 of Table 3) are similar to those of the benchmark model. The instrumental variable (IV) method was used to reduce endogeneity further. Two-period-lagged funding variables are typically used as instrumental variables, because they may be related to endogenous variables and the two-period lag may prevent them from affecting the error terms (Gujarati \& Porter, 2009). However, innovation projects always take longer to implement, which delays the impact of innovation funding. A two-period lag may not satisfy the assumption that instrumental variables should be exogenous. Therefore, a three-period lag was used as the instrumental variable. Columns 1 and 5 of Table 5 show that the IV model results for production and interest funding are consistent with those of the benchmark model, while Column 2 


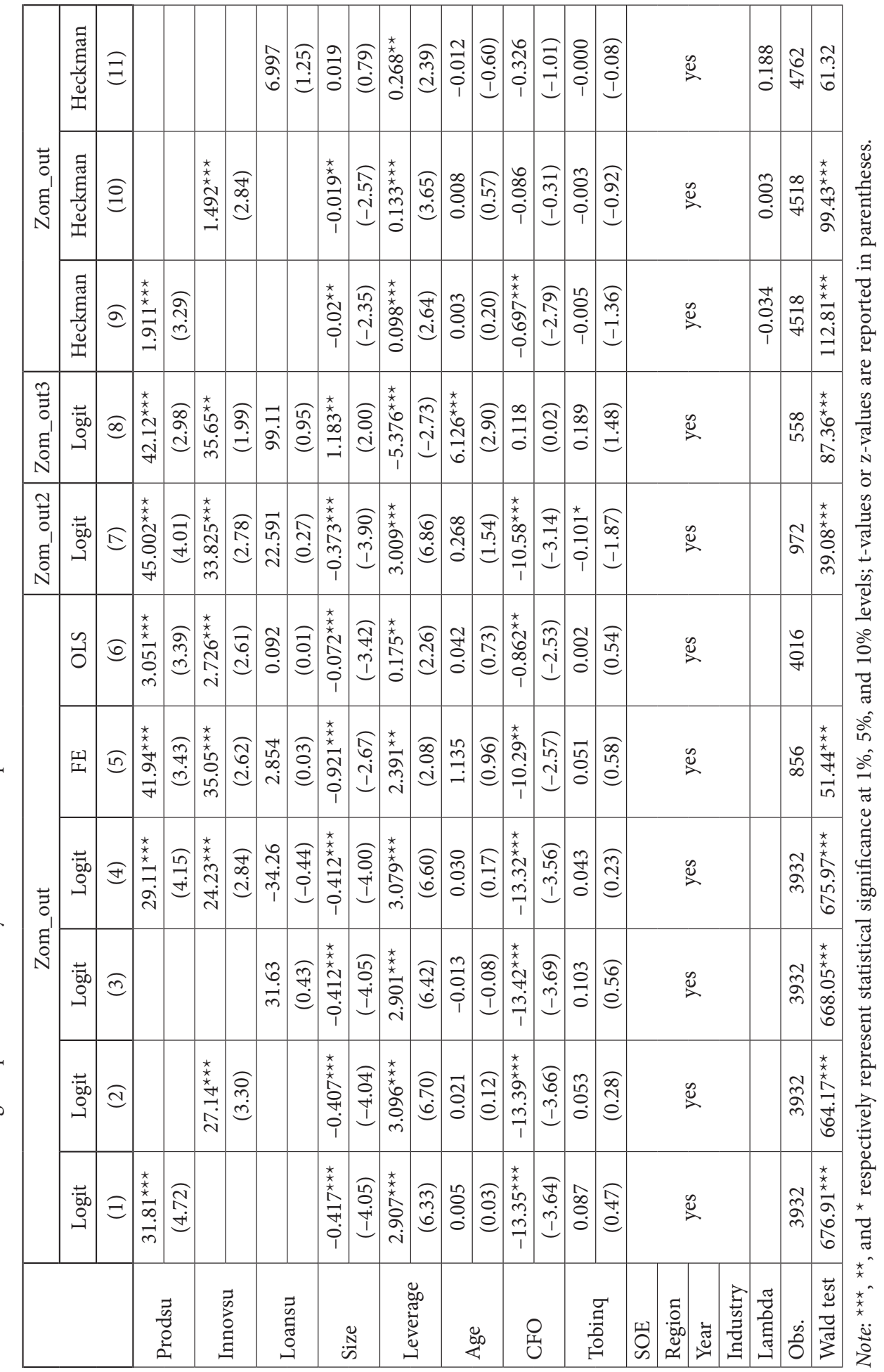


shows an insignificant coefficient of innovation funding. This may be because this study used five-year short panel data; the three-period lag of the innovation funding variable may have reduced the available sample data, producing an inconsistent result. To address this problem, referring to Clausen (2009), the mean value of innovation funding from one region (RAIns) was employed as the instrumental variable; the results are similar to those of the benchmark model (Column 3 of Table 5). This study also took the mean value of one region and that of one industry (IAIns) together as instrumental variables. The results are consistent and pass the tests of under-identification, weak identification, and over-identification (Column 4 of Table 5).

To test the robustness of results, the fixed effects model (FE) and ordinary least squares model (OLS) were employed, which produced consistent findings (Columns 5 and 6 of Table 3). This study also changed the measurement mode of the dependent variable. The traditional FN-CHK standard was employed to identify zombie enterprises and generate a new dependent variable, Zom_out $2_{i, t}$. Further, the samples that never become zombie enterprises were excluded, obtaining the other dependent variable, Zom_out $3_{i, t}$. The results using two substitution variables were stable (Columns 7 and 8 of Table 3). These results verify the reliability of Hypotheses $1 \mathrm{a}$ and $1 \mathrm{~b}$.

\subsection{Combined impact of government funding and industry life cycle}

This study also tested whether the industry life cycle can influence the effectiveness of government funding by classifying the industries into two categories using industrial scale data from the China Statistical Yearbook: (1) expanding industries, where the growth rate of sales is faster than the median for all industries; and (2) contracting industries, where the growth rate of sales is slower than the median for all industries.

The two subsamples were brought into the benchmark and Heckman models to investigate the combined impact of funding and the industry life cycle. The results (Columns 1 to 4 of Table 4) show that production and innovation funding can revive zombie enterprises in the expanding industries subsample, while funding for interest cannot. This means that Hypotheses $2 \mathrm{a}$ and $2 \mathrm{~b}$ are verified positively. It also suggests that the positive effect of production and innovation funding can only be realized under the condition of sufficient industrial demand. Furthermore, Columns 5 to 8 of Table 4 show that none of the three funding types can revive zombie enterprises in the contracting industries subsample. As analyzed above, contracting market demand may significantly reduce the positive impact of funding on zombie enterprises' recovery. Additionally, the lags of the funding variables were used as the instrumental variables, and the IV model subsample results (Columns 6 to 11 of Table 5) are similar to those of the benchmark model.

\subsection{Recovery mechanism of zombie enterprises}

To investigate the possible paths of zombie-enterprise recovery, production, innovation, and interest funding are taken into Model (7) respectively. The results are shown in Table 6. Columns 1 and 2 of Part 6-1 show that production funding has an insignificant impact on spending on selling, while the latter has a significantly positive impact on the recovery 


\begin{tabular}{|c|c|c|c|c|c|c|c|c|c|c|c|c|c|c|c|c|c|c|c|c|c|c|}
\hline 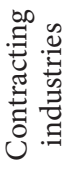 & 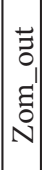 & . & $\Xi$ & 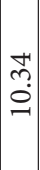 & $\begin{array}{l}10 \\
\infty \\
\stackrel{0}{9}\end{array}$ & $\mid \begin{array}{l}1 \\
0 \\
0 \\
0 \\
-1\end{array}$ & 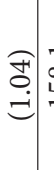 & 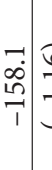 & 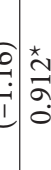 & $\begin{array}{l}\overparen{\partial} \\
\stackrel{\overbrace{}}{\ominus}\end{array}$ & $\mid \begin{array}{c}x \\
x \\
0 \\
0 \\
0 \\
0 \\
i \\
1\end{array}$ & 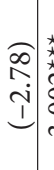 & 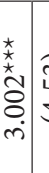 & 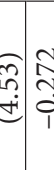 & 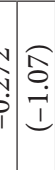 & 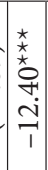 & 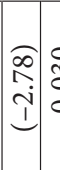 & 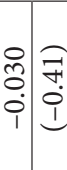 & 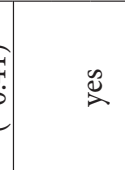 & & $\begin{array}{c}\stackrel{8}{0} \\
\infty \\
-1\end{array}$ & $\begin{array}{l}\stackrel{\star}{\star} \\
\stackrel{\star}{\star} \\
\stackrel{+}{+} \\
\stackrel{\infty}{+} \\
\stackrel{+}{+}\end{array}$ \\
\hline 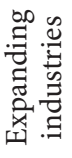 & 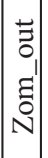 & . & 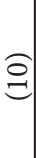 & 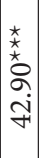 & శิ & 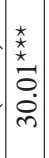 & 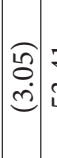 & $\begin{array}{c}7 \\
\dot{7} \\
\text { in }\end{array}$ & 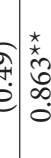 & 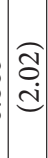 & $\left|\begin{array}{c|c}x \\
x \\
x \\
0 \\
0 \\
0 \\
0 \\
0 \\
1\end{array}\right|$ & \begin{tabular}{l}
0 \\
\multirow{2}{*}{} \\
$i$ \\
1
\end{tabular} & 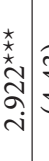 & 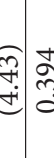 & 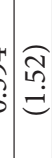 & $\mid \begin{array}{l}x \\
\vdots \\
\vdots \\
\vdots \\
\vdots \\
1 \\
1\end{array}$ & 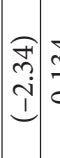 & 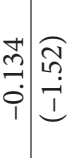 & $\stackrel{\infty}{2}$ & & \begin{tabular}{l}
0 \\
\multirow{2}{二}{}
\end{tabular} & 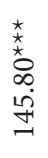 \\
\hline 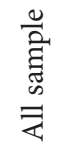 & $\begin{array}{l}\vec{z} \\
0 \\
\vdots \\
\vdots \\
0 \\
N\end{array}$ & . & $\widehat{\Xi}$ & 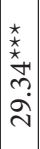 & తิ & 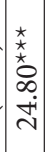 & 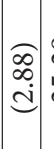 & તְָ̦⿱ & 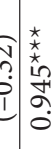 & 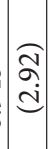 & 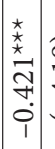 & 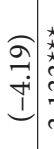 & 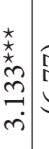 & 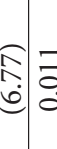 & : & 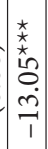 & $\begin{array}{c}2 \\
\vec{n} \\
\tilde{n} \\
1 \\
\end{array}$ & 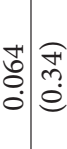 & $\stackrel{\mathscr{Z}}{\mathscr{2}}$ & & ふૈ & $\begin{array}{l}\stackrel{\star}{\star} \\
\stackrel{\star}{\star} \\
\stackrel{\infty}{+} \\
\stackrel{\hat{\sigma}}{6}\end{array}$ \\
\hline \multirow{3}{*}{ 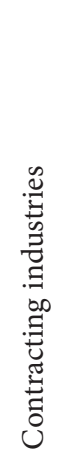 } & 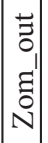 & 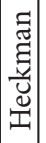 & $\infty$ & & & & & 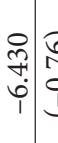 & & & $\begin{array}{c}\hat{\tilde{c}} \\
0 \\
0 \\
1\end{array}$ & 志 & $\begin{array}{l}\mathrm{N} \\
\hat{o} \\
\dot{0}\end{array}$ & 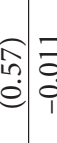 & $\begin{array}{l}\tilde{m} \\
n \\
0 \\
1\end{array}$ & 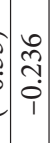 & 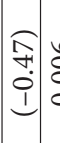 & 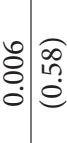 & $\stackrel{\infty}{2}$ & $\mid$\begin{tabular}{c}
20 \\
\multirow{2}{*}{} \\
\hdashline \\
1
\end{tabular} & $\begin{array}{l}0 \\
\vec{\sim} \\
\mathbb{N}\end{array}$ & $\begin{array}{l}\vec{n} \\
\infty \\
\dot{\gamma}\end{array}$ \\
\hline & $\begin{array}{l}\vec{z} \\
0 \\
\vdots \\
\Xi \\
0 \\
N\end{array}$ & 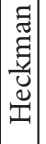 & $\Xi$ & & & $\mid \begin{array}{l}\hat{n} \\
\hat{n} \\
0\end{array}$ & $\begin{array}{l}\hat{f} \\
\stackrel{b}{e}\end{array}$ & & & & $\begin{array}{c}n \\
0 \\
0 \\
0 \\
1\end{array}$ & 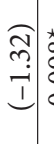 & 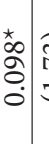 & 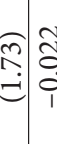 & 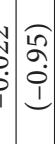 & $\left\{\begin{array}{c}0 \\
0 \\
-1 \\
1 \\
1\end{array}\right.$ & 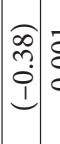 & 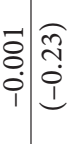 & $\stackrel{\mathscr{\nu}}{\varnothing}$ & $\mid \begin{array}{l}0 \\
\vdots \\
0 \\
0 \\
1 \\
1\end{array}$ & $\begin{array}{l}\stackrel{\sim}{\sim} \\
\vec{\sim}\end{array}$ & $\begin{array}{l}\text { D } \\
\text { in }\end{array}$ \\
\hline & $\left|\begin{array}{c} \pm \\
\vdots \\
\vdots \\
\Xi \\
\vdots \\
N \\
N\end{array}\right|$ & 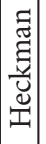 & 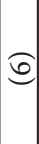 & $\frac{\infty}{\widetilde{1}}$ & $\begin{array}{l}\infty \\
\infty \\
\stackrel{\infty}{\ominus}\end{array}$ & & & & & & $\begin{array}{c}-1 \\
0 \\
0 \\
1 \\
1\end{array}$ & $\begin{array}{ll}\widehat{2} & \\
\hat{n} & x \\
\vdots & 1 \\
1 & 1\end{array}$ & 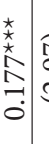 & 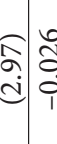 & 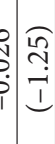 & 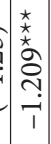 & $\mid \begin{array}{c}\overparen{f} \\
\stackrel{1}{0} \\
\dot{1} \\
\end{array}$ & $\begin{array}{ll}8 & 0 \\
0 & 0 \\
0 & 0 \\
& 1 \\
\end{array}$ & $\stackrel{\infty}{2}$ & $\mid \begin{array}{c}0 \\
\hat{0} \\
0 \\
0\end{array}$ & 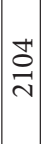 & 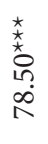 \\
\hline
\end{tabular}

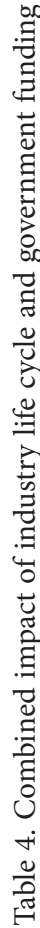

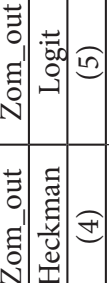

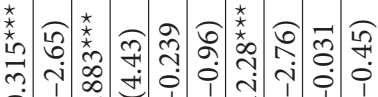

$\stackrel{\infty}{2}$

8

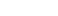

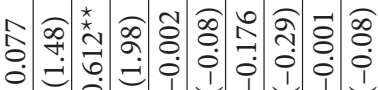

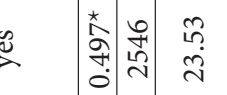

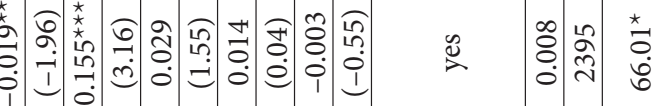
节 


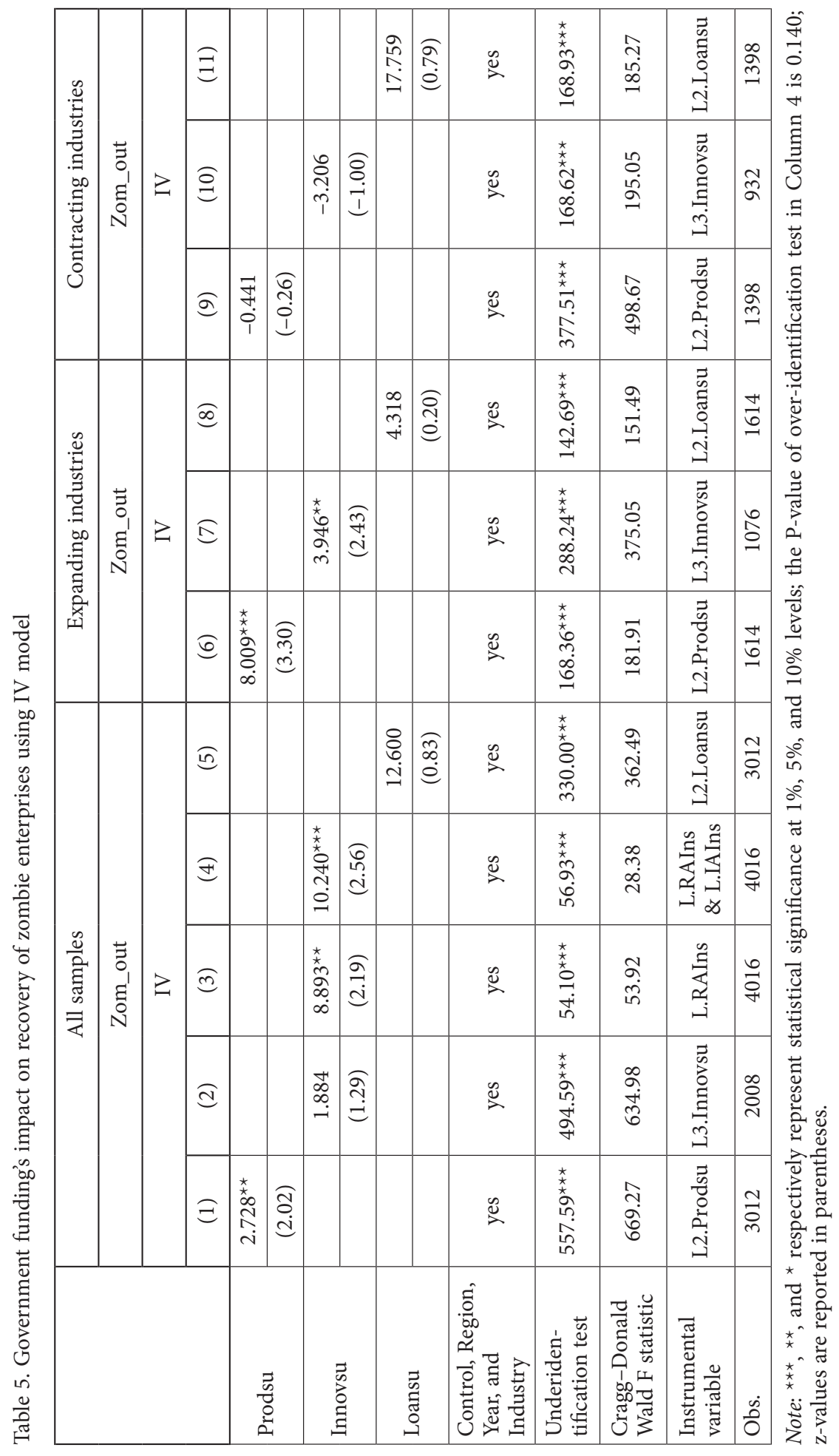




\begin{tabular}{|c|c|c|c|c|c|c|c|c|c|c|c|c|c|c|c|c|c|c|c|c|}
\hline & 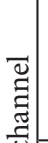 & 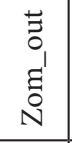 & $\stackrel{\overparen{త}}{\Xi}$ & 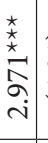 & 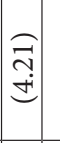 & & & & 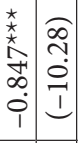 & 文 & $\begin{array}{l}0 \\
\hat{\sigma} \\
e \\
e\end{array}$ & & & 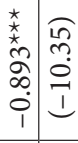 & $\underset{\substack{f \\
+\infty}}{+\infty}$ & 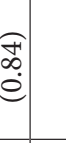 & & & 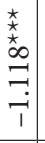 & 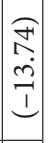 \\
\hline & 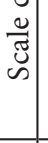 & $\begin{array}{l}\text { त्ँ } \\
\text { फ }\end{array}$ & $\Xi$ & 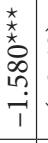 & 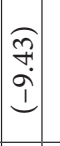 & & & & & 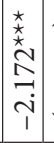 & 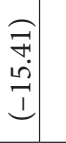 & & & & 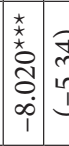 & 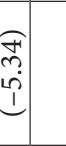 & & & & \\
\hline 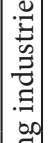 & 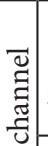 & $\Xi^{\prime} \stackrel{0}{0}^{\prime}$ & 을 & 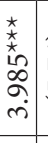 & $\begin{array}{l}\text { F } \\
\stackrel{1}{\text { in }} \\
\end{array}$ & & 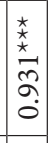 & $\mid \begin{array}{c}0 \\
\hat{n} \\
i n \\
0\end{array}$ & & 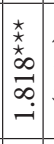 & $\begin{array}{l}\stackrel{f}{m} \\
\stackrel{n}{ }\end{array}$ & & 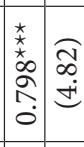 & & 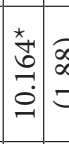 & \begin{tabular}{c}
$\infty$ \\
$\infty$ \\
$\infty$ \\
\hdashline \\
\hdashline
\end{tabular} & & 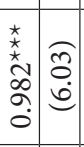 & & \\
\hline 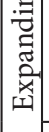 & $\begin{array}{l}\vec{\theta} \\
\overrightarrow{2} \\
\underline{2}\end{array}$ & 穴 & $\widehat{\sigma}$ & 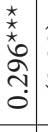 & $\begin{array}{c}\widehat{\hat{~}} \\
\stackrel{\tilde{c}}{2}\end{array}$ & & & & & 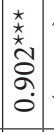 & 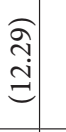 & & & & 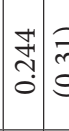 & $\begin{array}{c}\widehat{\vec{n}} \\
\stackrel{0}{e}\end{array}$ & & & & \\
\hline & 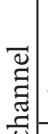 & 竎 & $\widehat{\infty}$ & 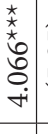 & $\begin{array}{ll}\mathscr{L} & \\
\infty & \\
10 & \\
0 & \\
& \end{array}$ & 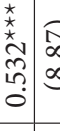 & & & & 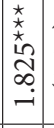 & 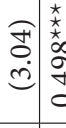 & 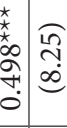 & & & 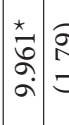 & 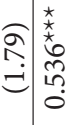 & 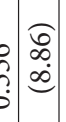 & & & \\
\hline & $\frac{0}{\tilde{n}}$ & $\frac{\mathscr{J}}{\text { ก }}$ & 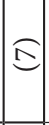 & \begin{tabular}{l}
$\infty$ \\
$\infty$ \\
0 \\
\hdashline \\
1 \\
1
\end{tabular} & 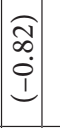 & & & & & 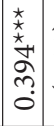 & $\stackrel{\infty}{\stackrel{\infty}{\leftrightharpoons}}$ & & & & 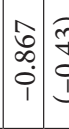 & 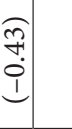 & & & & \\
\hline & 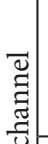 & 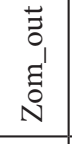 & 6 & 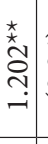 & 今િ & & & & 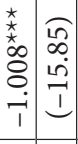 & $\begin{array}{c}\overrightarrow{\tilde{r}} \\
0 \\
\dot{i} \\
1\end{array}$ & $\begin{array}{l}\widehat{\widehat{O}} \\
\stackrel{0}{0} \\
\mathbf{1}\end{array}$ & & & 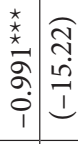 & 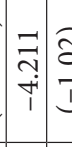 & $\begin{array}{l}\widehat{\widehat{\sigma}} \\
\dot{\underline{i}} \\
\end{array}$ & & & 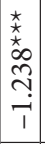 & 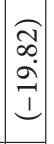 \\
\hline & $\begin{array}{l}\frac{0}{\widetilde{U}} \\
\tilde{W}\end{array}$ & 芯 & (동 & 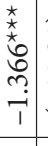 & 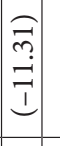 & & & & & 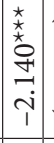 & $\begin{array}{c}0 \\
10 \\
\infty \\
T \\
1 \\
1\end{array}$ & & & & 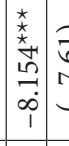 & 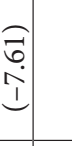 & & & & \\
\hline 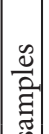 & 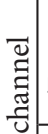 & 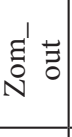 & $\overparen{\Xi}$ & 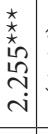 & $\begin{array}{l}\widehat{\sigma} \\
\stackrel{1}{+} \\
\dot{\Xi} \\
\end{array}$ & & 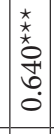 & ج্f & & 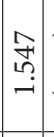 & $\begin{array}{l}\mathbb{n} \\
\tilde{m} \\
\stackrel{n}{0}\end{array}$ & & 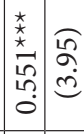 & & 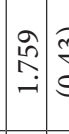 & $\begin{array}{l}\widehat{\tilde{q}} \\
\stackrel{5}{e}\end{array}$ & & 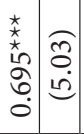 & & \\
\hline 至 & $\overrightarrow{\widehat{A}}$ & 芯 & $\widehat{(\approx)}$ & 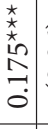 & 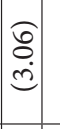 & & & & & 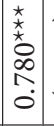 & 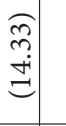 & & & & 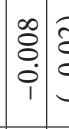 & $\begin{array}{l}\widehat{a} \\
\vdots \\
0 \\
1\end{array}$ & & & & \\
\hline & 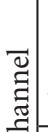 & छ̃ & $\widehat{(}$ & 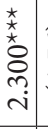 & 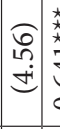 & 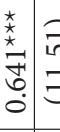 & & & & 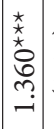 & 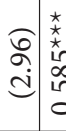 & 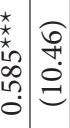 & & & 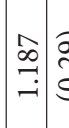 & 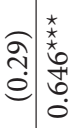 & 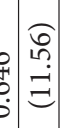 & & & \\
\hline & $\frac{0}{\tilde{n}}$ & $\frac{\mathscr{N}}{\tilde{n}}$ & $\Xi$ & $\begin{array}{c}c \\
0 \\
\stackrel{1}{0} \\
1\end{array}$ & $\mid \begin{array}{c}\widehat{N} \\
\hat{N} \\
1 \\
1\end{array}$ & & & & & 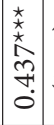 & $\begin{array}{l}\infty \\
\stackrel{\infty}{\infty}\end{array}$ & & & & 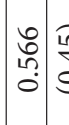 & 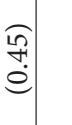 & & & & \\
\hline & & & & $\begin{array}{l}\vec{z} \\
\overrightarrow{0} \\
0 \\
0\end{array}$ & 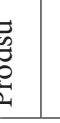 & $\frac{\tilde{N}}{\text { ஸే }}$ & A & $\vec{z}$ & 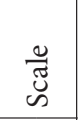 & 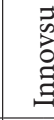 & 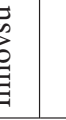 & $\frac{\ddot{N}}{\tilde{\omega}}$ & 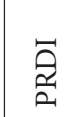 & 苟 & 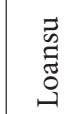 & t: & $\frac{\ddot{\pi}}{\tilde{D}}$ & 空 & & 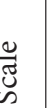 \\
\hline & & & & \multicolumn{6}{|c|}{$\begin{array}{l}\vec{b} \\
\vec{a} \\
\vec{a}\end{array}$} & \multicolumn{5}{|c|}{ 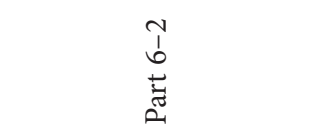 } & \multicolumn{6}{|c|}{ 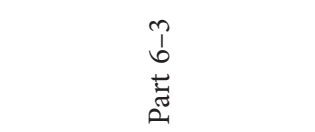 } \\
\hline
\end{tabular}


of zombie enterprises. This suggests that production funding cannot revive zombie enterprises by increasing spending on selling. However, Columns 3 and 4 of Part 6-1 report that funding for production can revive zombie enterprises by increasing private R\&D investment; this result supports the assertion according to the corporate-finance theory and signal theory. Production funding increases R\&D investment by alleviating the financial difficulties of zombies and helping them recover. Meanwhile, Columns 5 and 6 of Part 6-1 show that production funding can promote scaling down, thereby helping zombie enterprises recover. This also verifies the enterprise-strategy theory assertion that contracting the business can promote the recovery of corporate core competitiveness. Columns 7 to 12 of Part 6-1 show that the results from the expanding industry samples are consistent with the original results, verifying the robustness of findings.

Columns 1 and 2 of Part 6-2 in Table 6 show that innovation funding has a significantly positive impact on spending on selling, while the latter has a significantly positive impact on the recovery of zombie enterprises. This suggests that innovation funding can revive zombie enterprises by increasing spending on selling, thus reflecting a positive effect on cost sharing. Columns 3 to 6 of Part 6-2 show that innovation funding can also revive zombie enterprises by increasing private R\&D investment and promoting scaling down. Similar results are obtained using the expanding industry samples (Columns 7 to 12 of Part 6-2). The above results can still be supported by the theoretical analysis.

As Part 6-3 in Table 6 shows, interest funding does not affect the recovery of zombie enterprises by increasing spending on selling and private R\&D for either the full sample or the expanding industry sample. However, interest funding can help revive zombies by promoting scaling down. This result is analyzed in more detail in the next section.

\section{Discussion}

The results show that funding for production and innovation can revive zombie enterprises in industries at the demand-expansion stage of the industry life cycle, while funding for interest cannot. None of the funding types can revive zombie enterprises in industries at the demand-contraction stage of the industry life cycle. However, some results still need to be discussed further.

First, although the benchmark-model result shows interest funding to have an insignificant impact, the channel-model result shows that interest funding can help to revive zombie enterprises by promoting scaling down. The reason for this is possibly that the impact of interest funding on zombie-enterprise recovery likely includes channels with negative effects, which suppresses the positive effect of the business contraction channel. As the above theoretical analysis explains, interest funding can stimulate zombie enterprises to transform and upgrade, which may be why the positive effect is captured via the business contraction channel. However, the external governance effect of interest funding is insignificant owing to the free use of bank loans, which reduces zombie enterprises' motivation to recover. They may not devote all their loan resources to transformation and upgrading, which may be one reason for the negative effects that suppress the positive effects. This result conforms to the theoretical expectation. 
Second, the benchmark model shows that none of the three funding types can revive zombie enterprises in industries at the demand-contraction stage; whether they can be revived in other ways requires further discussion. As shown in the above analysis, zombie enterprises in contracting industries are difficult to revive, as they cannot bear the high innovation costs required for major technological changes. If the market demand for lowtechnology products increases and enhances their revenue, they can regain the ability to bear innovation costs for recovery. China is attempting to alleviate its severe structural overcapacity by promoting "Belt and Road" initiatives, in an effort to push Chinese products into the global market by investing in infrastructure construction in countries along the Belt and Road. Therefore, it is necessary to test whether increasing the exports of zombie enterprises in contracting industries can provide recovery opportunities. An explanatory variable for export intensity (Export) was introduced into the benchmark model. Column 11 in Table 4 indicates that exports positively affect the recovery of zombie enterprises. The results using all samples and the expanding industry samples are similar (Columns 9 and 10 of Table 4).

\section{Conclusions}

The effectiveness of government funding policies is often subject to constraints, such as funding types and the industry life cycle. Government funding may be an important factor in zombie enterprise formation. However, scientifically implemented government funding can also help zombie enterprises to share costs, improve technology, and optimize resource allocation, leading to their recovery.

The results show that funding for production and innovation can revive zombie enterprises, while funding for interest cannot; this supports the assertion of corporate-finance theory and signal theory that production funding can alleviate the financial difficulties of zombie enterprises. It also supports the assertion of external-governance theory and corporate-innovation theory, that production and innovation funding can induce transformation and upgrading and increase technology levels. Information-asymmetry theory can also help to explain the insignificant impact of interest funding.

Considering the impact of the industry life cycle, funding for production and innovation can revive zombie enterprises only in expanding industries, as sufficient market demand can provide conditions favorable to their transformation and upgrading. Meanwhile, interest funding has a weak external governance effect, due to zombie enterprises' free use of bank loans, and thus cannot revive them in expanding industries. In contracting industries, excessive transformation costs and a huge demand risk can neutralize the effect of government funding; thus, none of the three funding types can help zombies recover.

Furthermore, the recovery channels are tested. The results show that funding for production and innovation can increase investment in selling or innovation through sharing costs and promote the scaling down of businesses through external governance effects, thus helping zombie enterprises recover. Although interest funding may lead to a business contraction, the weak external governance effects cannot ensure zombie enterprises' 
willingness to transform, and thus cannot revive them. Zombie enterprises in contracting industries face fierce competition and high transformation costs; their recovery opportunities lie in accessing larger overseas markets, rather than government funding.

The findings suggest that production and innovation funding can revive zombie enterprises by sharing their costs in expanding industries. Therefore, the intensity of their production and innovation funding should be enhanced. Meanwhile, the government should strengthen the external governance effect of production and innovation funding by supporting key businesses and technologies with bright prospects. The government should also assist zombie enterprises in conducting business integration to improve operational efficiency, while strengthening supervision on projects that receive interest funding to ensure that the loans are inducing corporate transformation and upgrading.

Government funding has no significant impact on the recovery of zombie enterprises in contracting industries. Therefore, the government should reduce funding for them and allow market mechanisms to play the key role in resource allocation. Bankruptcy and restructuring should be used to weed out uncompetitive zombie enterprises and boost the efficiency of those contracting industries. Additionally, the government should continue to strengthen cooperation with countries along the Belt and Road to provide conditions favorable for zombie enterprises' expansion to overseas markets, creating opportunities for their recovery.

This study still has several limitations. First, the sample comprises listed enterprises in China. Although this provides data for different government funding types, it may also produce sample selection bias. The Heckman model has been used to address this concern, but richer approaches should be used in future studies. Another problem is the limited sample size. Listed enterprises are representative but are far fewer than unlisted ones; thus, the sample size should be expanded. Moreover, this study discusses only manufacturing enterprises because their production and innovation activities differ from those of service enterprises. Future studies should analyze the differences and similarities in effects between the service and manufacturing industries. Additionally, this study discusses the effects of three government funding types, but the effects of tax policy also require attention. Finally, this study discusses only the favorable recovery channels; future studies could also examine the channels that hinder recovery.

\section{Funding}

This work was supported by National Natural Science Foundation of China under Grant [No.71873027]; National Natural Science Foundation of China under Grant [No.72072028]; Humanities and Social Science Foundation of Ministry of Education of China under Grant [No.18YJA790063].

\section{Author contributions}

Yudi Yang: Methodology, Writing-Original draft preparation \& Revising. Yong Qi: Conceptualization, Writing-Review \& Editing. Shuo Yang: Data curation, Software. 


\section{Disclosure statement}

The authors have no competing financial, professional, or personal interests from other parties.

\section{References}

Ahearne, A. G., \& Shinada, N. (2005). Zombie firms and economic stagnation in Japan. International Economics and Economic Policy, 2(4), 363-381. https://doi.org/10.1007/s10368-005-0041-1

Caballero, R. J., Hoshi, T., \& Kashyap, A. K. (2008). Zombie lending and depressed restructuring in Japan. American Economic Review, 98(5), 1943-1977. https://doi.org/10.1257/aer.98.5.1943

Chang, Q., Zhou, Y., Liu, G., Wang, D., \& Zhang, X. (2020). How does government intervention affect the formation of zombie firms? Economic Modelling, 94, 768-779.

https://doi.org/10.1016/j.econmod.2020.02.017

China National Intellectual Property Administration. (2009). Patent search and analysis. http://pss-system.cnipa.gov.cn/sipopublicsearch/portal/uiIndex.shtml

Clausen, T. H. (2009). Do subsidies have positive impacts on R\&D and innovation activities at the firm level? Structural Change and Economic Dynamics, 20(4), 239-253. https://doi.org/10.1016/j.strueco.2009.09.004

Dai, X., Qiao, X., \& Song, L. (2019). Zombie firms in China's coal mining sector: identification, transition determinants and policy implications. Resources Policy, 62, 664-673. https://doi.org/10.1016/j.resourpol.2018.11.016

Fang, M., \& Sun, K. (2019). Can mixed ownership reform of SOEs cure zombie firms? A mixed ownership pecking order logic. Journal of Financial Research, 463(1), 91-110. (In Chinese). http://www.jryj.org.cn/CN/Y2019/V463/I1/91

Fukuda, S., \& Nakamura, J. (2011). Why did "zombie" firms recover in Japan? World Economy, 34(7), 1124-1137. https://doi.org/10.1111/j.1467-9701.2011.01368.x

Gao, J., \& Li, M. (2018). Dealing strategies of "zombie enterprises": A review of domestic research. Contemporary Economics, 1, 36-39. (In Chinese).

Gujarati, D. N., \& Porter, D. C. (2009). Basic econometrics (5 ${ }^{\text {th }}$ ed.). McGraw-Hill. https://cbpbu.ac.in/userfiles/file/2020/STUDY_MAT/ECO/1.pdf

Heckman, J. J. (1979). Sample selection bias as a specification error. Econometrica, 47, 153-161. https://doi.org/10.2307/1912352

Huang, S., \& Chen, Y. (2017). The distribution features and classified disposition of China's zombie firms. China Industrial Economics, 3, 24-43. (In Chinese). https://doi.org/10.19581/j.cnki.ciejournal.2017.03.002

Huang, T., \& Guo, K. (2019). Research on state-owned zombie firm's exit mechanism based on evolutionary game theory. Business Management Journal, 5, 5-20. (In Chinese). https://doi.org/10.19616/j.cnki.bmj.2019.05.001

Huergo, E., \& Moreno, L. (2017). Subsidies or loans? Evaluating the impact of R\&D support programmes. Research Policy, 46(7), 1198-1214. https://doi.org/10.1016/j.respol.2017.05.006

Imai, K. (2016). A panel study of zombie SMEs in Japan: Identification, borrowing and investment behavior. Journal of the Japanese and International Economies, 39, 91-107. https://doi.org/10.1016/j.jjie.2015.12.001

Jaskowski, M. (2015). Should zombie lending always be prevented? International Review of Economics and Finance, 40, 191-203. https://doi.org/10.1016/j.iref.2015.02.023 
Jiang, L., \& Lu, Y. (2017). Does minimum wage standard inhibit the formation of new zombie firms. China Industrial Economics, 11, 118-136. (In Chinese).

https://doi.org/10.19581/j.cnki.ciejournal.2017.11.010

Jiang, L., Lu, Y., \& Chen, Y. (2018). Can market mechanism help to cure zombie firm? Evidence from FDI liberation. The Journal of World Economy, 9, 121-145. (In Chinese).

Jiang, H., \& Wang, X. (2018). A study on the "zombie firms" problem of listed companies-an empirical analysis of cause and revival based on logit model. East China Economic Management, 32(10), 161-167. (In Chinese). https://doi.org/10.19629/j.cnki.34-1014/f.180606002

Kane, E. (1987). Dangers of capital forbearance: The case of the FSLIC and "zombie" S\&Ls. Contemporary Economic Policy, 5(1), 77-83. https://doi.org/10.1111/j.1465-7287.1987.tb00247.x

Kwon, H., Narita, F., \& Narita, M. (2015). Resource reallocation and zombie lending in Japan in the 1990s. Review of Economic Dynamics, 18(4), 709-732. https://doi.org/10.1016/j.red.2015.07.001

Li, X., Lu, J., \& Jin, X. (2018). Zombie firms and tax distortion. Management World, 34(4), 127-139. (In Chinese). https://doi.org/10.3969/j.issn.1002-5502.2018.04.011

Lin, Y. P. (2011). Zombie lending, financial reporting opacity and contagion. National University of Singapore. https://scholarbank.nus.edu.sg/handle/10635/77714

Liu, G., Zhang, X., Zhang, W., \& Wang, D. (2019). The impact of government subsidies on the capacity utilization of zombie firms. Economic Modelling, 83, 51-64.

https://doi.org/10.1016/j.econmod.2019.09.034

Luan, Q., Luo, S., Xiong, Q., \& Luo, J. (2018). Can government R\&D subsidies save zombie firms? An empirical study based on small and medium-sized enterprises in Shanghai. Forum on Science and Technology in China, 10, 39-45. (In Chinese). https://doi.org/10.13580/j.cnki.fstc.2018.10.005

Maksimovic, V., \& Phillips, G. (2008). The industry life cycle, acquisitions and investment: Does firm organization matter? Journal of Finance, 63(2), 673-708. https://doi.org/10.1111/j.1540-6261.2008.01328.x

Markides, C. C. (1995). Diversification, restructuring and economic performance. Strategic Management Journal, 16(2), 101-118. https://doi.org/10.1002/smj.4250160203

Meuleman, M., \& Maeseneire, W. D. (2012). Do R\&D subsidies affect SMEs' access to external financing? Research Policy, 41(3), 580-591. https://doi.org/10.2139/ssrn.1099346

Nakamura, J., \& Fukuda, S. (2013). What happened to "zombie" firms in Japan?: Reexamination for the lost two decades. Global Journal of Economics, 2(2), 1-18. https://doi.org/10.1142/S2251361213500079

Nie, H., Jiang, T., Zhang, Y., \& Fang, Y. (2016). Research report on Chinese zombie enterprises: Current situation, reasons and countermeasures. Serial Reports of National Academy of Development and Strategy, RUC, 9. (In Chinese).

Niu, L., \& Gao, L. (2018). Government subsidy saves life or continues life: An analysis of causes of zombie firms. Science-Technology and Management, 20(3), 86-96. (In Chinese). https://doi.org/10.16315/j.stm.2018.03.006

Peek, J. (2008). The contribution of bank lending to the long-term stagnation in Japan. University of Kentucky.

Peng, H., Mao, X., \& Zhang, Y. (2020). Government innovation subsidy and executives entertainment spending perks - considering the effect of external governance and positive emotion. Management Review, 32(3), 122-135. (In Chinese). https://doi.org/10.14120/j.cnki.cn11-5057/f.2020.03.014

Porter, M. E. (1990). The competitive advantage of nations. Macmillan.

Rao, J., \& Wan, L. (2018). Government subsidy, heterogeneity and the formation of zombie firms: Evidence from China’s listed companies. Accounting Research, (3), 3-11. (In Chinese).

https://doi.org/10.3969/j.issn.1003-2886.2018.03.001 
Shen, G. (2016). Comparative advantages and zombie firms: A study based on new structural economics. Management World, (12), 13-24. (In Chinese). https://doi.org/10.19744/j.cnki.11-1235/f.2016.12.003

Shen, G., \& Chen, B. (2017). Can mixed ownership zombie firms and over-capacity in Chinese manufacturing. China Economic Review, 44, 327-342. https://doi.org/10.1016/j.chieco.2017.05.008

Song, J., Su, Z., \& Wang, D. (2019). Government subsidies and the formation of zombie firms: based on constraint types of firms. Finance \& Trade Economics, 40(4), 5-19. (In Chinese). https://doi.org/10.3969/j.issn.1002-8102.2019.04.002

Tan, Y., Tan, Z., Huang, Y., \& Wing, T. W. (2017). The crowding-out effect of zombie firms: Evidence from China's industrial firms. Economic Research Journal, 5, 175-188. (In Chinese). http://voxchina.org/show-3-128.html

Tan, Y., Huang, Y., \& Woo, W. T. (2016). Zombie firms and the crowding-out of private investment in China. Asian Economic Papers, 15(3), 32-55. https://doi.org/10.1162/ASEP_a_00474

Wang, Y., Li, W., \& Dai, Y. (2018). How do zombie firms affect innovation? Evidence from China's industrial firms. Economic Research Journal, 11, 99-114. (In Chinese).

Wang, W., \& Liu, X. (2018). Why do zombie firms survive for a long time. China Industrial Economics, 10, 61-79. (In Chinese). https://doi.org/10.19581/j.cnki.ciejournal.2018.10.004

Xu, K., Geng, C., Wei, X., \& Jiang, H. (2020). Financing development, financing constraint and $\mathrm{R} \& \mathrm{D}$ investment of strategic emerging industries in China. Journal of Business Economics and Management, 21(4), 1010-1034. https://doi.org/10.3846/jbem.2020.12727

Zhang, A., Wang, S., Liu, B., \& Fu, J. (2020a). The double-edged sword effect of diversified operation on pre- and post-loan risk in the government-led Chinese commercial banks. North American Journal of Economics and Finance, 54, 101246. https://doi.org/10.1016/j.najef.2020.101246

Zhang, C., Chen, Y., \& Zhou, H. (2020b). Zombie firms and soft budget constraints in the Chinese stock market. Asian Economic Journal, 34(1), 51-77. https://doi.org/10.1111/asej.12194

Zhang, D., Xie, Z., \& Wang, J. (2016). China's zombie companies and their detection - an exploratory research based on listed companies in iron and steel industry. China Industrial Economics, 11, 90-107. (In Chinese). https://doi.org/10.19581/j.cnki.ciejournal.2016.11.008

Zhou, J., Xian, G., \& Ming, X. (2018). The recognition and warning of zombie enterprises: Evidence from Chinese listed companies. Journal of Finance and Economics, 44(4), 130-142. (In Chinese). https://doi.org/10.16538/j.cnki.jfe.2018.04.010

Zhu, Z., Zhang, S., \& Huang, X. (2018). Can outward direct investment cure zombie firms - a study based on the perspective of firm-level markups. Journal of International Trade, 8, 108-120. (In Chinese). https://doi.org/10.13510/j.cnki.jit.2018.08.009 